\title{
Capital controls to manage foreign exchange reserves and foreign debts*
}

\author{
Chokri Zehri ${ }^{1}$
}

\begin{abstract}
The study explores the relationship between foreign exchange reserves (FER) and foreign borrowing $(F B)$ within the framework of the management of capital flows. To investigate this relationship and examine the effect of capital control on foreign exchange reserves and external debt of two approaches are applied, the panel vector autoregression model (PVAR) and a traditional model of the reserve demand for 25 emerging countries over the period 1985-2019. The results show a negative association between FER and FB; the direction of the causality was from debts to reserves. Capital controls, as an instrument to reduce the short-term inflows, fail to restrict the accumulation of exchange reserves and conversely, succeed in limiting the recourse to foreign borrowing. Net foreign assets replacing foreign exchange reserves highlights different impacts of capital controls and raise the issue on a correct evaluation of foreign exchange reserves.
\end{abstract}

Key words: capital controls, debts, reserves, foreign assets

JEL classification: $f 32, f 36, f 37$

\section{Introduction}

By considering the domestic outputs, the rise in foreign exchange reserves (FER) is now a recent discussion by financial policymakers. Moreover, the high volume of FER in emerging economies is supposed to have affected real interest rates, current account, and exchange rates (Aizenman and Jinjarak, 2019). According to Kharusi and Ada, (2018) FER are accumulated as a guarantee opposing the spillover risk of financial instability. Frequently, financial unbalances have a slight impact on

\footnotetext{
* Received: 06-03-2020; accepted: 05-06-2020

1 Assistant Professor of Economics, Prince Sattam Bin Abdulaziz University, College of Sciences and Humanities in Al-Sulail. Department of Business Administration, Saudi Arabia. Scientific affiliation: international financial liberalization, capital controls \& financial crisis. Phone: +966554907434; Fax: +966117822251.E-mail: c.alzhari@psau.edu.sa.
} 
economies with a large stock of FED. Many countries, such as China, Hong Kong, Taiwan, and Singapore, have accumulated reserves, and all seemed to be relatively unharmed (Obstfeld et al., 2010). The accumulation of such reserves is achieved through a positive trade surplus and a large save of foreign currencies.

Likewise, the foreign borrowing (FB) increased at high levels for emerging economies, notably, for Asian and Latin American economies (Figure 1). The rise in FB is caused by the incentives created by the capital account openness that ease access to external funding (Aizenman, Jinjarak, and Park, 2015). Several reasons for this exorbitant progress are suggested as implications of financial openness. Developing economies approved this process and were decreased with the 2008 crisis by the adoption of capital controls particularly in the short term.

The analysis applies a panel of 25 emerging countries experienced with capital controls for the period 1985-2019. Table 1-A in appendix displays the list of these countries which are defined as emergent according to the IMF classification.

On the first hand, the study contributes to previous studies by employing a recent approach based on a panel VAR regression (Abrigo and Love, 2016). This approach allows using jointly panel data with VARs. A vast literature has focused on the explanation of foreign exchange reserves by foreign borrowing, but, surprisingly, few studies examine the reverse relationship that explains foreign borrowing by reserves.

On the second hand, the study examines the impact of restrictive policies using capital controls on FER and FB (Eichengreen and Mody, 1999). As a response to the detrimental effects of capital account openness, emergent economies have reintroduced capital controls to limit the short-term capital inflows (Magud, Reinhart, and Kenneth, 2018; Farhi and Werning, 2014; Zehri and Abdelkarim, 2020). An optimal combination between reserves accumulation, external debts, and restrictive policies on capital flows is considered crucial to the financial system stability (Aizenman et al., 2006; Jeanne and Ranciere, 2006). The empirical evidence suggests that capital controls may be an obstacle to the accumulation of exchange reserves when it reduces capital flow movements (Farhi and Werning, 2014). Similarly, capital controls reduce access to external credit markets and therefore reduces the recourse to external debt (Bachetta et al., 2013).

Through a traditional model of the demand for reserves (Lane and Burke, 2001; Obstfeld et al., 2010), the study highlights the function of FB in the reserve's possession. The restrictive policy on capital flows, proxy by a dummy variable 'tax', has also a crucial role to examine their impacts on FER and FB. Consequently, the main three policies often used in the optimal management of capital flows literature, FER, FB, and capital controls, were included in the empirical models (Jeanne, 2007; 2010). Many debates have also emerged about elements composing international reserves. The main is considering gold as part of foreign exchange 
reserves (Flood et al., 2001). The study employs the variable 'total of reserves and related items' as defined by the World Bank (WDI database). For robustness checks and to be more precise about the definition of international reserves, the study uses the net foreign assets (NFA) instead of the international reserves variable (FER).

The results highlight a clear relationship between foreign exchange reserves and external debts. In terms of causality, the direction exists from FER to FB, the opposite sense does not appear. These findings are also confirmed throughout the Impulse Response Functions analysis (IRFs), which shows a clear response of FB to a shock on FER, and oppositely, any response is detected for a shock of FER on FB. The restrictive policies using capital controls did not prevent emerging countries from accumulating exchange reserves, while it reduced foreign borrowing. Given the employ of net foreign assets as a dependent variable, the behavior of capital controls has changed providing an adverse impact on the accumulation of nets foreign assets.

The research hypotheses arising from the previous debate are summarized as follow:

H1: FER can be explained by FB and no relationship can be identified for the opposite sense.

H2: Capital controls serve to reduce capital inflows and then to decrease the accumulation of FER.

H3: Capital controls, as an instrument of restrictive policies, will reduce the recourse to FB.

H4: Net foreign assets, considered as a substitute to FER, will have the same impacts of capital controls as on exchange reserves.

The paper is organized as follows. The next section presents the literature review of the relationships FER, FB, and capital controls. The second section presents the models' specification. Section three is divided into three parts; the first details the PVARs analysis. The second regresses a traditional model of international reserves. The third, for robustness check, introduce net foreign assets that substitute FER variable. The last section concludes and provides proposals for well-managing capital controls.

\section{Literature review}

Recent studies have highlighted the reasons for the buildup in official reserves in emerging markets since the 1980s. Ghosh et al., 2017 suggest that international reserves are accumulated as preventive demand against both current- and capitalaccount shocks, furthermore as an effective policy to deal with the exchange rate 
undervaluation. As a result of capital account crises of the 1990s, particularly in Asian countries in 1997, prevention against capital account shocks has become crucial and requires a satisfactory stock of foreign exchange reserves. The export booms following these crises have demonstrated the benefits of undervalued currencies for export-led growth. In the 2008 financial crisis, the undervaluation of the currency became also important in explaining the accumulation of reserves. This undervaluation can be deliberate through sterilized intervention. The author highlight that emerging economies are becoming more risk-averse and have learned that the potential shocks are larger than previously.

The literature evidence highlight the excessive capital flows to emerging economies and approve, in some cases, the relationship between the FER with FB (Koepke, 2019). Primarily, raising resort to external debts gives a boost to reserve aggregation. Secondly, the accumulation of FER can be substituted by many possibilities of FB. If external transactions can be supported via debt, fewer reserves are required (Mody and Murshid, 2005). At the same time, a large volume of reserves can be considered as a guaranty to contract new external debts. International capital markets become more stable with a high stock of reserves accumulated. Contrarily, rollover risk and the likelihood of lender shocks are intensified when liquid assets are non-abundant (Feldstein, 1998).

Some other studies find several difficulties to establish a clear link between reserves and external debts (Summer 2006; Jeanne and Korinek, 2011). For a country, that recourse to foreign lenders and desires to apply an effective financial policy needs to analyze the ratios relating to both variables (reserves and debts). Unfortunately, the huge stock of FER holding by emergent countries cannot be only clarified by the standard ratio of reserves sufficiency (Cerutti et al., 2019). Moreover, the main sources of exchange reserves come from international trade, and regarding this framework, any relationship was found for FER and FB or vice versa (Eaton and Gersovitz, 1980). Landell-Mills (1989) suggest the possibility to obtain a root of funding reserves from borrowing, but international transactions are usually carried out directly by debt.

The theoretical and empirical literature on reserves/debts relationship can be approached in multiple ways. The study groups those under three concepts mainly debated in the managing capital flows literature: Guidotti-Greenspan rule; sudden stop and fire sale and prevention of financial instability.

\subsection{Guidotti-Greenspan Rule, 1999}

After the Korean crisis, a new rule of thumb is discussed by the International Monetary Fund. This rule consists to build a ratio regrouping the short-term external debt with the reserves sufficiency. Greenspan and Guidotti suggested that the economy should manage its foreign assets and their external debts. They 
propose the "Guidotti-Greenspan rule" which country must accumulate reserves with sufficient amount to cover the external liabilities and to remain without the resort to external debt for at least one year.

Greenspan (1999) improves "Guidotti-rule" by introducing a slight novelty that the maturities of external debts must surpass a determined period, for example, 3 years. He also suggests using a "liquidity-at-risk" standard for which an economy must hold reserves that allow a strong probability to not resort to external debt for at least one year (95\% probability). Some studies consider that emerging economies need to have adequate reserves relative to the demand for short-term external debt (Bussiere and Mulder, 1999). Therefore, these economies present a small trend to hold few reserves once they have a high level of short-term debt. Some studies disagree with this rule (Summers, 2006), they show that it was not respected by several emerging countries.

\subsection{Sudden stop and fire sale}

The damaging effects of short-term external debts in foreign currency are determined through many features such as an increase in the costs of a sudden stop, constraints in the credit market, and more exposition to financial vulnerabilities (Eichengreen, Hausmann and Panizza, 2003). Such effects conduct costly and precocious liquidation of investments. These effects become more intense when the level of foreign exchange reserves is low. This process can lead to higher deleveraging costs and lower resale price of investments (fire sale) Aizenman (2009). In emerging economies, the rise in the foreign currency demand increases the deleveraging pressure. Consequently, this pressure conducts an overvaluation of the exchange rate specifically when foreign exchange reserves are low and restricted. This will prompt banks to sell a large part of their investments to finance the repayment of their external debts.

Each bank supposes the feasible fire-sale price as a cluster. This is then considered as a fire-sale externality, somewhat similar to saturation (Krugman, 2000). Many studies are focused on the literature of "sudden stop" for capital inflows to analyze the relationship between FER, FB, and capital controls. Calvo and Reinhart (2000) suggest that developing economies can be creditworthy of their external liabilities when it was big inflows and unfortunately, solvency becomes more difficult in sudden stops periods and when these flows leave the country. Arce, Bengui, and Bianchi (2019) analyze a theoretical model of guarantee dealing with sudden-stop events. The combination of external debt, international reserves, and controls are analyzed when investors are risk-averse and the socks on productivity are equally distributed.

The possession of a satisfactory stock of international reserves and external debts will prompt effective tax smoothing. The ratio of FER to short-term external debt 
tended to fulfill a prevent indicator of financial instability. Besides, the empirical studies are lesser decisive about the role of exchange reserves to predict financial crises. Some studies search for an optimal policy for managing capital flows (Jeanne and Rancière, 2006). Facing the random sudden stop, the authors define an optimal level of international reserves in a model explaining the smooth of national consumption. Summer (2006) contradicts previous studies by suggesting that the sudden stops theory presents many shortcomings, specifically a failure to prevent crises. This conclusion is valid also for economies that accumulate reserves exceeding the "Guidotti-Greenspan rule".

\subsection{Prevention of financial instability}

The facts show that accumulating more exchange reserves relative to shortterm external debt gives security to deal with an eventual financial instability in comparison to countries with few reserves. The ratio of international reserves / external short-term debt is considered in many empirical studies as the main variable to signal a financial crisis. Also, the IMF studies praise this ratio as the most significant forecaster of reserves adequacy in developing countries (Jeanne 2010 and IMF 2000). Short-term external debt is considered by Obstfeld et al. (2010) as an effective predictor of financial vulnerability specifically for the emerging countries. The reserves accumulation favors liquidity availability and reduces the vulnerability of an economy to external shocks, specifically with poor macroeconomic conditions. In the same way, Bussiere and Mulder (1999) show that short-term external debt as a percent of international reserves constitute a practical measure applied effectively to individual economy cases. The authors also utilize the log-ratio of short-term external debt to GDP as a further variable to their regressions explaining fluctuations of international reserves. Other studies suggest a simple benchmark for adequacy reserves (Wijnholds et al. 2001). Many variables are used in this benchmark but the most significant is the ratio of reserves to external debts.

Some studies are focused on the social cost generated by holding FER. Rodrick (2006) estimates that the cost of holding reserves is expensive as the cost of foreign borrowing. The study proposes to reduce the level of FB instead of holding reserves and this proposition is more suitable for the case of emergent economies. Other studies are searching for an ideal policy to manage of FER, FB, and capital controls (Bianchi and Mendoza, 2018; Korinek 2010; Jeanne and Korinek 2011). In circumstances where households face borrowing constraints, Bachetta et al. (2013) have noted that the equilibrium of a liberalized economy might not be socially effective and if the three policies (FER, FB, and capital control) are well combined they can ameliorate the welfare. Jeanne (2010) has suggested that the optimal level of reserves is equal to short-term external debt level added by the cost of the crisis, and minus the opportunity cost of reserves accumulation. 
Figure 1: Increase in total reserves and short-term external debt in (a) South Asia; (b) Latin America
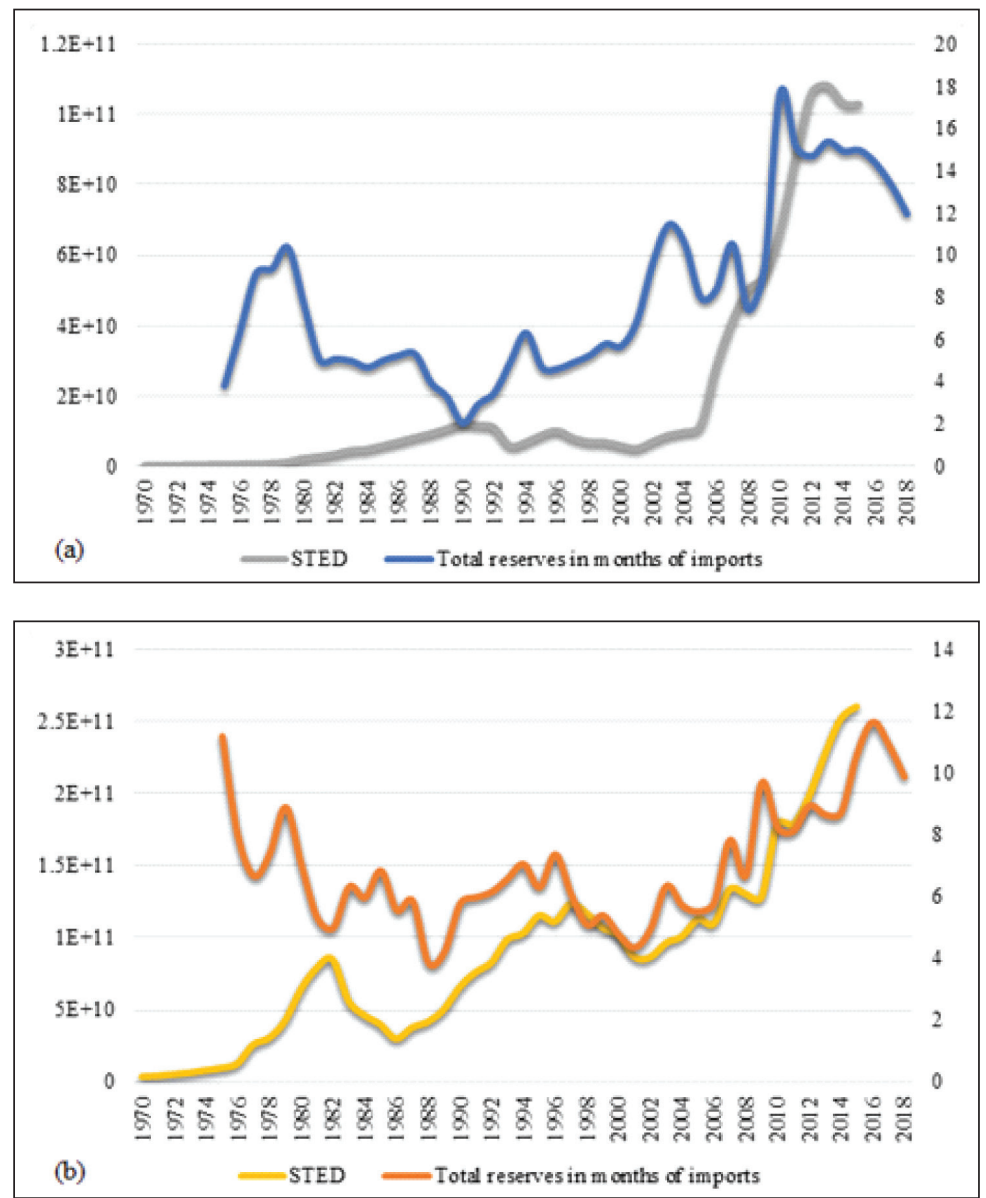

Source: author's illustration

\section{Methodology}

Many recent studies examine the linkage of international reserves and external debts using panel regressions (Espinoza, 2014; Qian and Steiner, 2017; Arce et al. 2019), but any of them has investigated this relationship with a panel VARs model (PVAR). Compared to other empirical methods, the panel VARs presents many advantages. First, when there are few theoretical studies on this relationship, the use of the VARs is recommended for the guidance of the model formulation. For our study, rare is the theoretical literature that examines, particularly, the causality from FB to FER. Second, the endogeneity bias presents a serious problem for many 
empirical studies. Glick and Hutchison (2005); Kharusi and Ada (2018) and Qian and Steiner (2017) all take in consideration this problem of endogeneity, and have tried to solve it by including a lagged variables or by imposing additional restrictions to their regressions. VARs may reduce the endogeneity bias by considering all variables as probably endogenous. Third, following the VARs regressions, we can obtain the impulse response functions which record any retarded effects of the considered variables; the classical panel models are unable to display these dynamic effects. The missed variable bias is also considered with panel VARs by employing the country fixed effects, which catch time-unchanging parts that may affect both foreign exchange reserves and foreign debts. Panel VARs has also the merit to be used with a short temporary scale which may be compensated by the gain from the cross-sectional scale.

The first part of the empirical analysis employs a PVAR approach in which a system of two regressions relating foreign exchange reserves (FER) and foreign borrowing (FB) is presented. These equations will allow finding the causality direction between FER and FB. The PVAR models with specific random effects are defined as follows:

$$
\begin{aligned}
& F E R_{i, t}=\alpha_{1} F E R_{i, t-1}+\alpha_{2} F E R_{i, t-2}+\ldots \beta_{1} F B_{i, t}+\beta_{2} F B_{i, t-1}+\ldots+\delta X_{i t}+u_{i}+e_{i t} \\
& F B_{i, t}=\alpha_{1} F B_{i, t-1}+\alpha_{2} F B_{i, t-2}+\ldots \beta_{1} F E R_{i, t}+\beta_{2} F E R_{i, t-1}+\ldots+\delta X_{i t}+u_{i}+e_{i t}
\end{aligned}
$$

Where FER: foreign exchange reserves; FB: foreign borrowing. $X_{i t}$ : the vector of explanatory variables of FER and FB (trade, M2, GDP, pop, expo). $u_{i}$ and $e_{i t}$ are vectors of dependent variable-specific panel random effects and idiosyncratic errors, respectively.

The second part aims to determine the impact of capital controls on foreign exchange reserves and foreign borrowing. Unfortunately, no previous study is made for this issue. The most robust path is to use a traditional model of the demand for reserves and to include our proxy of capital controls. We follow the studies of Obstfeld et al., 2010; Lane and Burke, 2001; Aizenman et al., 2003 who also employed this model. We include our dummy variable "tax" as a proxy of capital controls to explain the logarithm of FER. This dummy variable cannot be introduced in the PVAR model for robustness reasons for the model. The traditional model of reserves used is defined as follow:

$$
\begin{aligned}
& \ln (\text { FER }) t=\alpha_{0}+\alpha_{1} \ln (\text { pop }) t+\alpha_{2} \ln (\text { trade }) \mathrm{t}+\alpha_{3} \ln (F B) t+\alpha_{4}(\text { tax })_{t}+ \\
& +\alpha_{5} \ln (M 2) t+\alpha_{6} \ln (\text { expo }) t+\alpha_{7} \ln (G D P) t+\varepsilon t
\end{aligned}
$$

Similarly, we define the model explaining foreign borrowing as follow:

$$
\begin{aligned}
& \ln (F B) t=\alpha_{0}+\alpha_{1} \ln (\text { trade }) t+\alpha_{2} \ln (\text { pop }) \mathrm{t}+\alpha_{3} \ln (F E R) t+\alpha_{4}(\text { tax })_{t}+ \\
& +\alpha_{5} \ln (M 2) t+\alpha_{6} \ln (\text { expo }) t+\alpha_{7} \ln (G D P) t+\varepsilon t
\end{aligned}
$$




\section{Empirical data and analysis}

The empirical literature highlights a set of variables explaining foreign exchange reserves and external debts. We present here a brief review of these variables. Heller (1966) has begun the modern study of optimal international reserves and shows the big role of trade openness (trade) in the accumulation of reserves. The population (pop) is also considered a relevant variable, it measures the country's size. When the size of the country is large it may accumulate more reserves and resort more often to external debts (Lane and Burke, 2001). The financial depth is an explicative variable of international reserves and foreign borrowing. According to Obstfeld et al. (2010), the size of domestic financial liabilities is proxy by the M2/GDP ratio (M2) that can be shifted into foreign currency. The export volatility (expo) offers a prudential incentive for keeping international reserves and usually presented as a proxy for international financial instability (Aizenman and Marion, 2003). The Gross Domestic Product per capita $(G D P)$ considered the most representative macroeconomic indicator of a country's economic strength. With a high GDP growth rate, the country may increase international reserves and will enjoy the confidence of borrowers to have more external debts (Grubel, 1971; Frenkel, 1974; Landell-Mills, 1989; Bordo and Eichengreen, 1998). The capital controls constitute the main variable of the study. These controls are proxy by "tax" that takes 0 for no capital controls and 1 when controls exist. This dummy variable is set by monitoring the dates of instituting restrictions on capital flows in each country of the sample. The variables FER and FB will be defined, respectively, as dependent variables in equation (3) and (4) and if not will be presented among the explanatory variables to define their impacts on each other (Cheung and Ito, 2009). The data of all variables are gathered from two main sources, the International Financial Statistics database (IFS) of the International Monetary Fund and the World Development Indicators (WDI) of the World Bank.

Table 1 summarizes the variables used in the empirical models. The de jure capital controls "tax" range from 0 to 1 (any controls to largest controls applied). The average controls are high (0.7) showing a tightness of restrictions among the sample countries. The standard deviation is low $(0.15)$ proving the difficulty moving to a higher level of restrictions. The descriptive statistics highlight the great part of foreign exchange reserves, foreign borrowing, and net foreign assets in the global economy of emergent economies. The average across countries is superior to $20 \%$ of the country's GDP. It was noticed a clear disparity and large heterogeneity of their accumulation across countries (the standard deviation exceed 10 for FER, FB, and NFA). 
Table 1: Summary statistics

\begin{tabular}{|l|c|c|c|c|}
\hline \multicolumn{1}{|c|}{ Variable } & Mean & Std. Dev & Min & Max \\
\hline FER & 21.30 & 11.05 & 3.96 & 52.89 \\
\hline FB & 22.99 & 13.25 & 6.90 & 67.84 \\
\hline GDP & 3.61 & 0.56 & -0.45 & 18.24 \\
\hline pop & 17.13 & 1.91 & 12.33 & 21.05 \\
\hline M2 & 13.81 & 2.64 & 2.20 & 35.34 \\
\hline expo & 24.31 & 1.49 & 20.69 & 28.60 \\
\hline trade & 14.12 & 0.61 & 2.21 & 54.39 \\
\hline tax & 0.71 & 0.15 & 0 & 1 \\
\hline NFA & 35.27 & 12.54 & 8.36 & 52.95 \\
\hline
\end{tabular}

Source: author's calculations

In the first part, the study employs PVARs to examine the linkage between the two variables, FER and FB. The study considers that the impact of the variables, on each other, appears only after one year at least, for this reason, we apply one delay on these variables. The following table displays the results of the PVARs analysis.

Table 2: PVAR analysis for FER and FB

\begin{tabular}{|l|l|c|c|c|c|c|c|}
\hline & & Coefficient & Std. Err. & $\mathrm{Z}$ & \multicolumn{2}{c|}{$\mathrm{P}>|\mathrm{z}|$} & \multicolumn{2}{|c|}{$[95 \%$ Conf. Interval] } \\
\hline \multirow{6}{*}{ FER } & FER_1 & 0.01 & 0.05 & 0.17 & 0.86 & -0.99 & 0.11 \\
\cline { 2 - 9 } & FB_1 & -0.22 & -0.56 & -4.00 & 0.00 & -0.33 & -0.11 \\
\cline { 2 - 8 } & trade_1 & 3.54 & 0.46 & 7.58 & 0.00 & 2.62 & 4.45 \\
\cline { 2 - 8 } & M2_1 & -1.87 & 0.44 & -4.21 & 0.00 & -2.74 & -0.99 \\
\cline { 2 - 8 } & pop_1 & -1.48 & 0.23 & -8.76 & 0.00 & -2.87 & -1.56 \\
\cline { 2 - 9 } & expo_1 & 2.03 & 0.32 & 7.58 & 0.00 & 2.43 & 4.36 \\
\cline { 2 - 9 } & GDP_1 & 0.22 & 0.22 & 1.00 & 0.31 & -0.21 & 0.65 \\
\hline \multirow{6}{*}{ FB } & FER_1 & -0.74 & 0.28 & -2.62 & 0.01 & -0.12 & -0.01 \\
\cline { 2 - 8 } & FB_1 & 0.79 & 0.03 & 21.24 & 0.00 & 0.72 & 0.87 \\
\cline { 2 - 8 } & trade_1 & 0.28 & 0.15 & 1.86 & 0.06 & -0.14 & 0.57 \\
\cline { 2 - 8 } & M2_1 & -1.01 & 0.16 & -6.03 & 0.00 & -1.35 & -0.68 \\
\cline { 2 - 8 } & pop_1 & -2.48 & 0.25 & -9.76 & 0.00 & -2.91 & -1.98 \\
\cline { 2 - 8 } & expo_1 & 0.36 & 0.28 & 1.96 & 0.04 & -0.24 & 0.64 \\
\cline { 2 - 8 } & GDP_1 & 0.82 & 0.98 & 8.36 & 0.00 & 0.63 & 1.01 \\
\hline
\end{tabular}

Source: author's calculations 
PVAR is followed by a Granger causality analysis to determine the direction of the causality of FER and FB. The causal relationship, as detailed above, remains undefined, and this section will allow us to shed some light on this debate. The results of the causality test are presented in Table 3 .

Table 3: Granger causality test

\begin{tabular}{|c|c|c|c|c|}
\hline Equation & Excluded & Chi2 & df & Prob > chi2 \\
\hline \multirow{4}{*}{ FER } & FB & 15.98 & 1 & 0.000 \\
\cline { 2 - 5 } & trade & 27.32 & 1 & 0.000 \\
\cline { 2 - 5 } & M2 & 17.69 & 1 & 0.000 \\
\cline { 2 - 5 } & pop & 8.95 & 1 & 0.003 \\
\cline { 2 - 5 } & GDP & 1.004 & 1 & 0.316 \\
\cline { 2 - 5 } & expo & 30.11 & 1 & 0.002 \\
\cline { 2 - 5 } & ALL & 187.31 & 6 & 0.000 \\
\hline \multirow{5}{*}{ FB } & FER & 6.83 & 1 & 0.319 \\
\cline { 2 - 5 } & trade & 3.46 & 1 & 0.063 \\
\cline { 2 - 5 } & M2 & 36.32 & 1 & 0.000 \\
\cline { 2 - 5 } & pop & 45.12 & 1 & 0.000 \\
\cline { 2 - 5 } & GDP & 69.97 & 1 & 0.000 \\
\cline { 2 - 5 } & expo & 50.10 & 1 & 0.003 \\
\cline { 2 - 5 } & ALL & 248.67 & 6 & 0.000 \\
\hline
\end{tabular}

Source: author's calculations

The analysis is deviously based on a demand for reserves model in which, after controlling the explanatory variables (trade, M2, pop, expo, GDP), the impact of FER on FB is interpreted as evidence of theoretical and empirical literature. We do this by relying on the orthogonalization of impulse responses (IRFs). This method detail the reply of one variable to the changes in a different variable in the VARs, with keeping all other changes equal to zero (Abrigo and Love, 2016).

Figure 2 draws the evolution of the IRFs. 
Figure 2: IRFs for equations 1 and 2

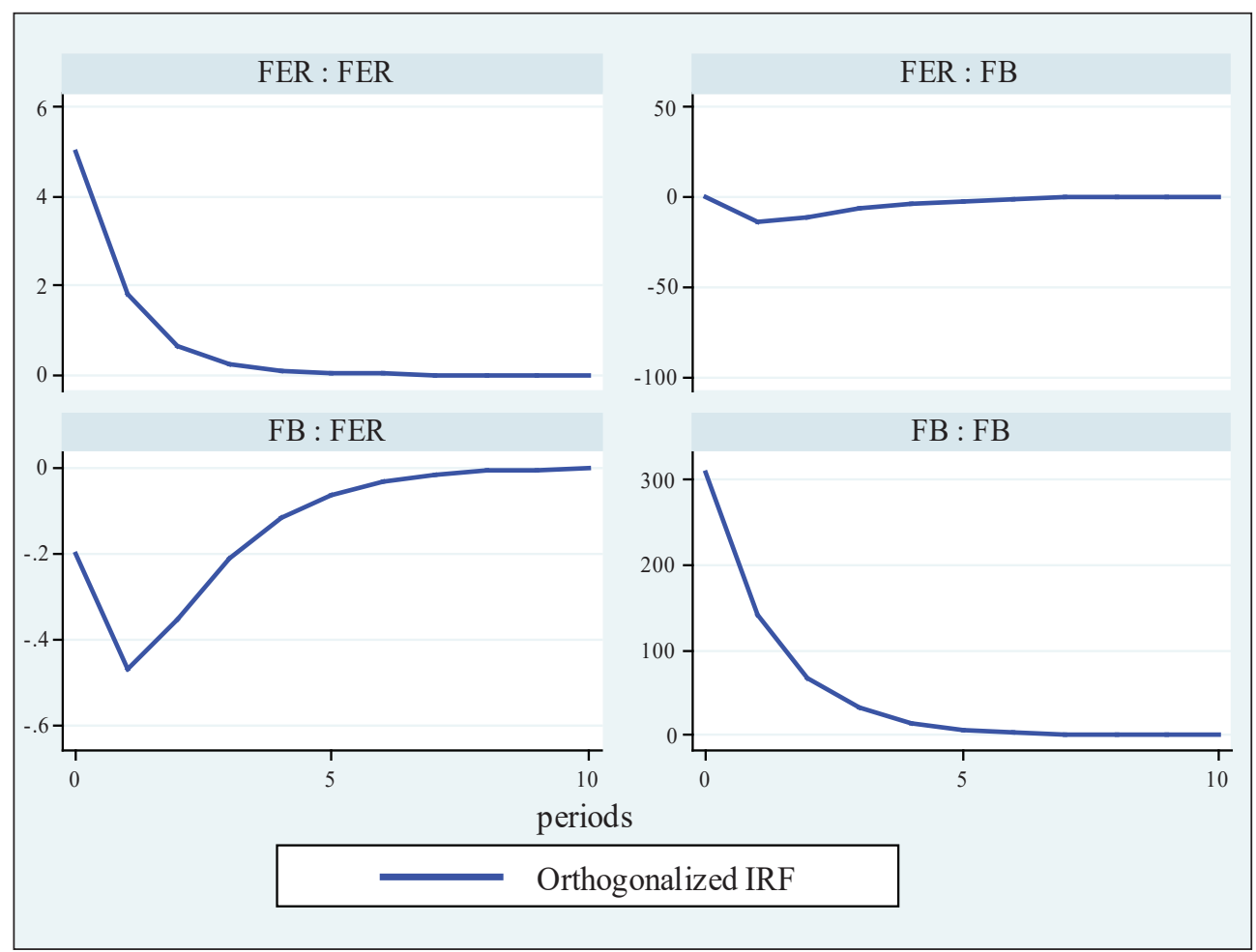

Source: author's calculations

In the second part, the study employs the traditional model of the demand for reserves. First, we explain the foreign exchange reserves by the control variables previously detailed, by the proxy of capital controls "tax", and by foreign borrowing variable. Second, we regress the same model using FB as the dependent variable. Tables 4 and 5 display respectively, the results of the regression for equations 3 and 4 . 
Table 4: Regression model FER $=\mathrm{f}(\mathrm{FB}$, tax $)$

\begin{tabular}{|l|c|c|c|c|c|c|}
\hline \multicolumn{1}{|c|}{ FER } & Coefficient & Std. Err. & $Z$ & $\mathrm{p}>|\mathrm{z}|$ & \multicolumn{2}{c|}{$\begin{array}{c}\text { 95\% Confidence } \\
\text { Interval] }\end{array}$} \\
\hline FB & -0.09 & 0.04 & -0.24 & 0.81 & -0.09 & 0.07 \\
\hline tax & 0.51 & 0.21 & 2.40 & 0.01 & 0.09 & 0.94 \\
\hline GDP & 0.82 & 0.10 & 8.08 & 0.00 & 0.62 & 1.02 \\
\hline pop & 0.91 & 0.13 & 6.72 & 0.00 & 0.64 & 1.17 \\
\hline M2 & 0.19 & 0.24 & 0.81 & 0.42 & -0.28 & 0.68 \\
\hline expo & 0.80 & 0.36 & 2.19 & 0.02 & 0.08 & 1.52 \\
\hline trade & 0.61 & 0.23 & 2.65 & 0.02 & 0.15 & 1.06 \\
\hline cons & -4.66 & 2.61 & -1.79 & 0.07 & -9.77 & 0.45 \\
\hline
\end{tabular}

Source: author's calculations

Table 5: Regression Model FB $=\mathrm{f}(\mathrm{FER}$, tax $)$

\begin{tabular}{|l|c|c|c|c|c|c|}
\hline \multicolumn{1}{|c|}{ FB } & Coefficient & Std. Err. & $Z$ & $\mathrm{p}>|\mathrm{z}|$ & \multicolumn{2}{c|}{$\begin{array}{c}\text { 95\% Confidence } \\
\text { Interval] }\end{array}$} \\
\hline FER & 0.28 & 0.27 & 1.02 & 0.30 & -0.25 & 0.81 \\
\hline tax & -0.32 & 0.76 & -2.48 & 0.04 & -0.23 & 0.81 \\
\hline GDP & 0.62 & 0.18 & 3.29 & 0.00 & 0.25 & 0.99 \\
\hline pop & -1.10 & 0.40 & -2.73 & 0.01 & -1.89 & -0.31 \\
\hline M2 & 0.82 & 0.39 & 2.08 & 0.03 & 0.04 & 1.60 \\
\hline expo & 0.80 & 0.36 & 2.19 & 0.02 & 0.08 & 1.52 \\
\hline trade & 0.70 & 0.37 & 1.91 & 0.05 & -0.01 & 1.43 \\
\hline cons & 21.63 & 6.22 & 3.48 & 0.01 & 9.44 & 33.83 \\
\hline
\end{tabular}

Source: author's calculations

Several critics have been addressed to the exact definition of foreign exchange reserves, their components, and the problem to consider gold as part of this variable (Flood et al., 2001). When foreign exchange reserves are measured by international financial institutions, several items may be introducing to this measure, among them there is especially a debate regarding gold. In practice and as an example, the European central banks, in 2000, retained approximately $\$ 226$ billion of foreign-exchange reserves, not including their large gold holdings. Flood et al., (2001) have found that the trends are modified when measured reserves include gold holdings. These later represent an interesting part of countries' reserve assets within the guidance of the Bretton Woods arrangement. Several empirical analysis has examined the factors of financial crises in the 1980s and 1990s by employing a reserves calculation that excludes gold. Thus if models of reserve accumulation 
over the last forty years are to be reviewed, gold must be considered. Our study uses the definition of the World Bank that define foreign exchange reserves by "reserves and related items" that include gold holdings.

As a response to this puzzle and for robustness check, the study replaces FER by nets foreign assets (NFA). The following model is regressed using NFA as the dependent variable and Table 6 displays the results of this regression.

Table 6: Regression Model NFA $=\mathrm{f}(\mathrm{FB}$, tax $)$

\begin{tabular}{|l|c|c|c|c|c|c|}
\hline \multicolumn{1}{|c|}{ NFA } & Coefficient & Std. Err. & $\mathrm{Z}$ & $\mathrm{p}>|\mathrm{z}|$ & \multicolumn{2}{c|}{$\begin{array}{c}95 \% \text { Confidence } \\
\text { Interval }]\end{array}$} \\
\hline FB & 0.29 & 0.98 & 0.34 & 0.02 & 0.36 & 4.23 \\
\hline tax & -0.36 & 5.17 & -2.06 & 0.04 & -20.82 & -0.50 \\
\hline GDP & 1.49 & 3.89 & 0.38 & 0.70 & -6.16 & 9.14 \\
\hline pop & 0.30 & 1.63 & 4.44 & 0.00 & 43.65 & 72.95 \\
\hline M2 & -0.32 & 6.02 & -0.88 & 0.37 & -17.17 & 6.51 \\
\hline expo & 0.13 & 0.28 & 2.54 & 0.03 & 0.07 & 1.63 \\
\hline trade & -0.01 & 6.33 & -2.72 & 0.01 & -29.66 & -4.76 \\
\hline cons & -3.38 & 7.83 & -5.54 & 0.00 & -13.96 & -9.81 \\
\hline
\end{tabular}

Source: author's calculations

The PVAR model (equation 1), explaining the FER by the determinants of reserves, show a negative and significant coefficient of FB (Table 2). This result confirms the findings of Lane and Burke (2001). The authors have studied the determinants of cross-country changes in the level of foreign-exchange reserves over 19811995. They establish some empirical linkage that may develop new theoretical patterning of reserves conduct. They consider Reserves as collateral for borrowing on world capital markets and as a determinant of the likelihood of default on credit. Similarly, few reserves may reflect an increased probability of default on credit markets and can conduct to greater debts charges which are commonly proxied by interest rate spreads on international financial markets. For emergent economies, the authors have found a partial negative correlation between the level of external debt and reserves.

This result is also in accordance with Obstfeld et al. (2010). The authors identified negative coefficients of foreign borrowing variables on reserves holdings. They developed a financial-stability model that explains reserve accumulation in the modern framework of globalized capital markets. Their main finding is that external debt factors for reserve accumulation highlight that a negative (capital outflow) balance-of-payments shock can arise from the capital account when the export assets to outside unexpectedly stop. 
The findings of the second equation, display also a negative association between the two variables. The FER coefficient is negative and significant showing that the accumulation of foreign exchange reserves reduces the country's foreign borrowing. With a significance level of $1 \%$, the PVAR Granger causality test displays only one direction causality from FER to FB (Table 3). Figure 2 reports graphs of IRFs for the VARs with two variables estimated (FER and FB) for the sample of countries. It supports our claim that FB explains the accumulation of FER and shows that the impact of the FB shock on FER takes more than 5 years until it goes out. Oppositely, no impact was found of FER on FB.

The second approach using a traditional model of the demand for reserves and including the capital controls proxy shows that emerging economies have succeeded to accumulate exchange reserves although the restrictive policy applied on capital flows. Table 4 displays a positive and significant coefficient of "tax" on reserves. This result is common to the China case. This country is known for its restrictive policy on capital movements while it is very active in the capital market by accumulating a huge stock of foreign exchange reserves. Bachetta et al. (2013) have suggested an optimal accumulation reserves model for China in which the Chinese central bank should motivate credits to the private sector and at the same time accumulate foreign exchange reserves. Capital controls do not pose a barrier to this process. The authors find that a country can benefit from rapid growth without applying capital account liberalization. In the Chinese context, they explain excessive reserve holdings by the interest rate spreads, domestically, and externally. The reserves accumulation in China has exceeded that of an open economy. Concerning the management of capital controls and foreign exchange reserves, Bachetta et al. (2013) have developed a model where households face a credit restriction; they found that an optimal competitive equilibrium of a liberalized economy can be reached with a combination of capital controls and reserve policy.

According to the results of Table 4, FB has a negative but insignificant association with FER. As previously debated, the direct relationship of FB to FER is weakly debated in the empirical literature. The insignificant coefficient of FB proves the difficulty to establish a clear relationship (Table 4). The result joins Lane and Burke (2001) and Obstfeld et al. (2010) who did not find any impact of external debts. Table 5 shows a negative and significant coefficient of 'tax', suggesting that capital controls may reduce debts contracted in foreign currencies. Globally, from the results of Tables 4 and 5, capital controls, applied by emerging countries, have failed to limit the accumulation of foreign exchange reserves and contrarily, succeed to reduce the level of external debts (Espinoza, 2014).

For the control variables, the most relevant findings are those of the M2 variable which is measured by the ratio M2/GDP. This variable accomplishes a major role in the rise of FB (Table 5), and at the same time, defines the vulnerability of an economy to the financial risks. The empirical literature on the financial crises 
(Obstfeld, 2012; Mulder et al., 1999; Glick and Hutchison, 2005 and De BeaufortWijnholds et al., 2001) consider the M2 monetary aggregate as a proxy of financial instability. This literature highlights a clear linkage between exchange reserves and financial instability. Reserve holdings are used as a key tool to deal with internal financial instability in a world of growing financial integration. Based on these studies, domestic financial liabilities including foreign currency, capital account openness, access to foreign currency through foreign borrowing markets, and exchange rate policy are all significant determinants of reserve holdings. Recently, Aizenman (2019) suggests that the liabilities of the financial system, especially, those denominated in foreign currency, are elements of M2 and a significant part of these liabilities comes from external debts. Excessive international reserves do not prevent a country's financial instability. Aizenman (2019) highlights the role of these external debts in this instability. He argues his opinion by the experience of Korea and Mexico during and after the world financial crisis. For these cases, a large stock of international reserves does not avoid a country from financial instability and it is above all a because of a heavy balance sheet of foreign currency loans.

The results of the replacement of FER by NFA are displayed in Table 6. The estimates show a positive coefficient of FB demonstrating that external debts encourage the accumulation of NFA. Contrarily, the coefficient of "tax" is negative and significant showing that capital controls reduce the NFA. The stocks of NFA are usually created by commercial banks and allow them to resort to external debts. This opportunity can be weakened by the use of capital controls, explaining the negative coefficient of "tax". Admitting that central bank has the authority to stock foreign exchange reserves and commercial banks can participate to the accumulation of net foreign assets, it can be assumed that the policies, sometimes divergent, of the central bank and the commercial banks, explain the changes in the sign of "tax" in the Tables 4 and 6.

\section{Results and discussion}

The study is part of the capital flows management framework and has developed significant results. The analysis has grouped three main policies often used in studies searching an optimal policy for managing capital flows: foreign exchange reserves, foreign borrowing, and capital controls.

Starting with examining the links that may exist between foreign exchange reserves and external debts, the results of the PVAR model confirmed this association. Table 2 shows significant coefficients of FB and FEF, respectively, in equations 1 and 2. The presence of this relation supports the theoretical literature previously detailed. When a country obtains external debts, this may raise the stock of exchange reserves, similarly, a country with highly stock reserves going to have the 
confidence of international borrowers to provide these debts denominated in foreign currency. These reserves constitute a kind of guarantee in the event of default of reimbursement.

Surprisingly, Table 2 shows a negative sign of both coefficients of FER and FB, stating a negative impact of external debts and exchange reserves, one upon the other. This can be explained by the fact that a country which has satisfactory foreign exchange reserves will not need to resort to external debt, and similarly, a country without a sufficient stock of foreign exchange reserves will request external credits to pay its international trade transactions. Thus, an inverse relationship is established which may explain the negative coefficients of reserves and external debts.

The results of the causality test displayed in Table 3, show causality in one direction, from FB to FER, and suggesting that external debts explain the evolution of foreign exchange reserves. These results are confirmed by the IRFs graphs which show that a shock on external debts will harm foreign exchange reserves and this impact survives 5 years before disappearing. Foreign exchange reserves are more sensitive to changes in external debts. The observation is obvious to what extent a large part of the foreign exchange reserves accumulated by the emerging countries come mainly from external debts. A shock to these debts (for example, a sharp drop in external debts) will negatively affect the reserve stock and this effect will last a long period. The second part of the study has introduced capital controls impacts. The results of the traditional model of the demand for reserves have shown these impacts on reserves and external debts.

Capital controls are part of a country's restrictive policy to reduce capital flows, especially short-term ones. These controls were expected to stop or at least reduce foreign exchange reserves, the results in Table 4 show a positive coefficient for the "tax" index and unexpectedly, capital controls did not prevent the accumulation of foreign exchange reserves. When a country applies capital controls it is mainly to prevent movements of speculative capital flows and not flows which bring in foreign exchange reserves. Restrictive policies applied by emergent economies, in terms of capital control, are selective and mainly target flows which harm the financial system (short-term speculative flows). Regarding the impact of capital controls on foreign borrowing, the coefficient of "tax" in Table 5 is significant and negative. This result highlights the adverse impact of controls on debts. At a later stage, they are harmful to the economy, especially when their levels are high. The establishment of capital controls, as previously detailed, will target these flows.

Considering net foreign assets as a close variable to foreign exchange reserves, the coefficient of "tax" in Table 6 presents a different impact of capital controls in which there is a reduction of NFA. These multiple results of "tax" still raise the debate, discussed in the previous section, on the dilemma to find an exact measure of foreign-exchange reserves. 
The study has contributed to the empirical literature of the management of capital flows by using two-approach PVAR and the traditional model of the demand for reserves. As our knowledge, it was the first time to examine the linkage between reserves and debts and to consider the role of capital controls within these approaches. The study gives some lessons to economic policymakers. On the one hand, a complementary or opposite linkage can be found between foreign-exchange reserves and external debts. This mainly depends on the objectives set by a country and according to the charges associated with the external debts. Foreign borrowing, if properly allocated, often considered as an engine for investment and growth. An arbitrage in terms of opportunity cost can be decided to resort to external debts or not. On the other hand, capital controls are instruments usually utilized to reduce short-term capital inflows. These controls must be oriented to the flows that harm the economy. The policymakers may evaluate the advantages and disadvantages of the entry of these flows, particularly those in forms of external debts. Depending on their undesirable effects, the intensity of capital controls to be established is decided. This explains why some countries have successfully used capital controls to promote their economy while others have failed. This debate leads us to open other research notably on the effectiveness of capital controls.

\section{Conclusions}

With the effort of emerging countries to reduce the high level of their external debts, we have noticed an increased accumulation of foreign exchange reserves. This observation has been demonstrated empirically following a negative relationship between the variables FB and FER. The results allow us to confirm the first research hypothesis with clear evidence on the impact of FB on FER, this impact is not approved in the opposite direction. The current account surpluses are performed by emerging countries that have accumulated sizable reserve stocks, and; therefore, lower their external debts.

The restrictive policy using capital control did not prevent emerging countries from increasing their stock of international reserves when these controls succeeded in reducing the recourse to external debt. The second hypothesis is infirmed, unexpectedly, the accumulation of exchange reserves is not stopped by capital controls, while, the third hypothesis is confirmed. Net foreign assets employed as a substitute for foreign exchange reserves show a different behavior of capital controls. These later reduce the accumulation of foreign assets, infirm the fourth hypothesis, and again raise the issue on the components to include in international reserves.

Several shortcomings can be addressed to this study, such as the choice of the proxy variable for capital controls "tax", several studies use other proxies, in particular, the KAOPEN index of Chinn and Ito and/or indexes established by monitoring the 
reforms provided by The Annual Report on Exchange Arrangements and Exchange Restrictions of the International Monetary Fund.

Other limits arise about the use of foreign exchange reserves, the exact definition of this variable differs across countries, we replaced it with nets foreign assets but the results found were different. Certainly, like any empirical analysis, inquiries can be asked about the choice of the empirical methods, the sample, the analysis period, etc. These shortcomings can serve as guidelines to improve the study, in particular with a more robust choice for capital control proxies, international reserves, etc. Likewise, resort to other types of models or to expand the sample and/or the analysis period.

In conclusion, while sustaining some of the previous studies, the paper also displays a simple approach that could be applied to further explore the optimal policy for managing capital flows across different countries. This optimal policy will undoubtedly involve the use of capital controls which will mainly target short-term external debts flows but which will keep the opportunity to the country to increase its stock of foreign-exchange reserves.

\section{References}

Abrigo, M.R., Love, I. (2016) "Estimation of panel vector autoregression in Stata", The Stata Journal, 16, 778-804, https://doi.org/10.1177/1536867x1601600314.

Aizenman, J., Jinjarak, Y. (2019) "Hoarding for Stormy Days-Test of International Reserves Providing Financial Buffer Services", No. w25909, National Bureau of Economic Research, https://doi.org/10.3386/w25909.

Aizenman, J. (2019) "A modern reincarnation of Mundell-Fleming's trilemma", Economic Modelling, 81, pp. 444-454, https://doi.org/10.1016/j.econmod.2018. 03.008 .

Aizenman, J. (2009) "Alternatives to sizeable hoarding of international reserves: Lessons from the global liquidity crisis", VoxEU. org, 30.

Aizenman, J. (2011) "Hoarding international reserves versus a Pigovian tax-cumsubsidy scheme: Reflections on the deleveraging crisis of 2008-2009, and a cost-benefit analysis", Journal of Economic Dynamics and Control, 35, pp. 1502-13, https://doi.org/10.3386/w15484.

Aizenman, J., Marion, N. (2003) "The high demand for international reserves in the Far East: What is going on?", Journal of the Japanese and international Economies, 17, 370-400, https://doi.org/10.1016/s0889-1583(03)00008-x.

Aizenman, J., et al. (2015) "Financial development and output growth in developing Asia and Latin America: A comparative sectoral analysis", No. w20917, National Bureau of Economic Research, https://doi.org/10.3386/w20917. 
Arce, F. et al. (2019) "A Macroprudential Theory of Foreign Reserve Accumulation", (No. w26236), National Bureau of Economic Research, https://doi.org/10.3386/ w26236.

Bianchi, J., Mendoza, E.G., (2018) "Optimal time-consistent macroprudential policy", Journal of Political Economy, 126 (2), pp. 588-634, https://doi. org/10.1086/696280.

Bordo, M. D. et al. (1998) "Was there really an earlier period of international financial integration comparable to today?", No. w6738, National Bureau of Economic Research, https://doi.org/10.3386/w6738.

Chinn, M. D., Ito, H. (2008) "A new measure of financial openness", Journal of comparative policy analysis, 10(3), pp. 309-322, https://doi.org/10.1080/ 13876980802231123.

Cerutti, E. et al. (2019) "Push factors and capital flows to emerging markets: why knowing your lender matters more than fundamentals", Journal of International Economics, 119, pp. 133-149, https://doi.org/10.1016/j.jinteco.2019.04.006.

Cheung, Y.W., Ito, H. (2009) "A cross-country empirical analysis of international reserves", International Economic Journal, 23(4), 447-481, https://oi.org/ 10.1080/10168730903372208.

Chang, R., Velasco, A. (2000) "Banks, debt maturity and financial crises", Journal of International Economics, 51(1), pp. 169-194, https://doi.org/10.1016/s00221996(99)00041-0.

Eaton, J., Gersovitz, M. (1980) "LDC participation in international financial markets: Debt and reserves", Journal of Development Economics, 7 (1), pp. 3-21, https://doi.org/10.1016/0304-3878(80)90025-5.

Eichengreen, B., Mody, A. (1999) "Lending booms, reserves, and the sustainability of short-term debt: Inferences from the pricing of syndicated bank loans", The World Bank.

Eichengreen, B. et al. (2003) "Currency mismatches, debt intolerance and original sin: why they are not the same and why it matters", No. w10036, National Bureau of Economic Research, https://doi.org/10.3386/w10036.

Espinoza, R. (2014) “A Model of External Debt and International Reserves”, Cerdi. org, 1-29.

Farhi, E., Werning, I. (2014) "Dilemma not trilemma? Capital controls and exchange rates with volatile capital flows", IMF Economic Review, 62 (4), pp. 569-605, https://doi.org/10.1057/imfer.2014.25.

Feldstein, M. (1998) "Refocusing the IMF", Foreign Affairs-New York, 77, pp. 20 33, https://doi.org/10.2307/20048786.

Fernández, A. et al. (2016) "Capital control measures: A new dataset". IMF Economic Review, 64(3), pp. 548-574, https://doi.org/10.1057/imfer.2016.11. 
Flood, R. et al. (2001) "Holding International Reserves in an Era of High Capital Mobility" [with Comments and Discussion], In Brookings trade forum (pp. 1-68). Brookings Institution Press, https://doi.org/10.1353/btf.2001.0007.

Glick, R., Hutchison, M. (2005) "Capital controls and exchange rate instability in developing economies", Journal of International Money and Finance, 24(3), pp. 387-412, https://doi.org/10.1016/j.jimonfin.2004.11.004.

Ghosh, A. R et al. (2017) "Shifting motives: Explaining the buildup in official reserves in emerging markets since the 1980s", IMF Economic Review, 65(2), pp. 308-364, http://dx.doi.org/10.1057/s41308-016-0003-3.

Holtz-eakin, D. et al. (1988) «Estimating vector autoregressions with panel data», Econometrica: Journal of the Econometric Society, pp. 1371-95, https://doi. org/10.2307/1913103.

Jeanne, O., Korinek, A. (2010) "Excessive volatility in capital flows: A Pigouvian taxation approach", American Economic Review, 100 (2), pp. 403-07, https:// doi.org/10.1257/aer.100.2.403.

Jeanne, O., Ranciere, R. (2011) "The optimal level of international reserves for emerging market countries: A new formula and some applications", The Economic Journal, 121 (555), pp. 905-30, https://doi.org/10.1111/j.1468-0297. 2011.02435.x.

Kelly, M. G. (1970). "The demand for international reserves". The American Economic Review, 60 (4), pp. 655-67, https://doi.org/10.1111/j.1540-6261.1970. tb00543.x.

Kharusi, S.A., Ada, M.S. (2018) "External debt and economic growth: The case of emerging economy", Journal of economic integration, 33(1), pp. 1141-1157, https://doi.org/10.11130/jei.2018.33.1.1141.

Koepke, R. (2019) "What drives capital flows to emerging markets? A survey of the empirical literature", Journal of Economic Surveys, 33(2), pp. 516-540, https:// doi.org/10.1111/joes.12273.

Korinek, A. (2010) "Excessive dollar borrowing in emerging markets: Balance sheet effects and macroeconomic externalities", https://doi.org/10.2139/ ssrn. 967524 .

Krugman, P. R. (2000) "The return of depression economics. WW Norton \& Company", The return of depression economics, https://doi.org/10.1007/ s12113-000-1015-3.

Landell-Mills, J. M. (1989) "The demand for international reserves and their opportunity cost”, Staff Papers, 36 (3), pp. 708-732, https://doi.org/10.2307/ 3867053.

Lane, P. R., Burke, D. (2001) "The empirics of foreign reserves", Open Economies Review, 12 (4), pp. 423-34, https://doi.org/10.3386/w8603. 
Magud, N. E. et al. (2018) "Capital Controls: Myth and Reality-A Portfolio Balance Approach", Annals of Economics and Finance, Society for AEF, 19 (1), pp. 1-47, https://doi.org/10.3386/w16805.

Mulder, M. C. B., Bussiere, M. M. (1999) "External vulnerability in emerging market economies: how high liquidity can offset weak fundamentals and the effects of contagion", International monetary fund, https://doi.org/10.5089/ 9781451851144.001.

Obstfeld, M. et al. (2010) "Financial stability, the trilemma, and international reserves", American Economic Journal: Macroeconomics, 2 (2), pp. 57-94, https://doi.org/10.1257/mac.2.2.57.

Obstfeld, M. (2012) "Financial flows, financial crises, and global imbalances", Journal of International Money and Finance, 31(3), pp. 469-480. https://doi. org/10.1016/j.jimonfin.2011.10.003.

Qian, X., Steiner, A. (2017) "International reserves and the maturity of external debt", Journal of International Money and Finance, 73, pp. 399-418, https:// doi.org/10.1016/j.jimonfin.2017.02.015.

Ranciere, R., Jeanne, M. O. (2006) "The optimal level of international reserves for emerging market countries: formulas and applications", no. 6-229, International Monetary Fund, https://doi.org/10.5089/9781451864892.001.

Reinhart, C. Calvo, G. (2000) "When capital inflows come to a sudden stop: Consequences and policy options", pp. 175-201, https://doi.org/10.1111/j.14657287.1994.tb00434.x.

Rodrik, D. (2006) "The social cost of foreign exchange reserves", International Economic Journal, 20 (3), pp. 253-66, https://doi.org/10.1080/10168730600879331.

Summers, L. H. (2006) "Reflections on global account imbalances and emerging markets reserve accumulation", L K Jha Memorial Lecture, Reserve Bank of India, Mumbai.

Wijnholds, J., Kapteyn, A. (2001) "Reserve adequacy in emerging market economies", https://doi.org/10.1057/9781137450661.0022.

Zehri, C., and Abdelkarim, G. M. (2020) "Effectiveness of capital controls to reduce short term flows", International Journal of Innovation, Creativity and Change, Volume 11, Issue 12, 2020, pp. 235-262. 


\title{
Kontrola kapitala u svrhu upravljanja deviznim pričuvama i inozemnim zaduživanjima
}

\author{
Chokri Zehri ${ }^{1}$
}

\begin{abstract}
Sažetak
U ovom radu istražuje se odnos između deviznih rezervi (FER) $i$ inozemnog zaduživanja (FB) u okviru upravljanja kapitalnim tokovima. Da bi se istražio ovaj odnos $i$ ispitao učinak kontrole kapitala na devizne pričuve i inozemne dugove za 25 zemalja u razvoju tijekom razdoblja 1985. - 2019.godine, primjenjena su dva pristupa: model autoregresije panelnih vektora (PVAR) i tradicionalni model potražnje deviznih pričuva. Rezultati pokazuju negativnu povezanost između FER-a i FB-a, a smjer uzročnosti je od dugova prema deviznim pričuvama. Kontrola kapitala, kao uspješna politika za ograničavanje kratkoročnih tokova, ne utječe na akumuliranje deviznih pričuva i, suprotno, smanjuje kratkoročne vanjske dugove. Korištenje neto inozemne imovine umjesto deviznih rezervi ukazuje na različite učinke kontrole kapitala i stoga se nameće pitanje o mogućnosti točne procjene deviznih pričuva.
\end{abstract}

Ključne riječi: kontrola kapitala, dugovi, rezerve, inozemna sredstva/inozemna imovina

JEL klasifikacija: F32, F36, F37

1 Docent, Prince Sattam Bin Abdulaziz University, College of Sciences and Humanities in AlSulail. Department of Business Administration, Saudijska Arabija. Znanstveni interes: međunarodna financijska liberalizacija, kontrola kapitala $i$ financijska kriza. Tel: +966554907434; Fax+966117822251.E-mail: c.alzhari@psau.edu.sa. 


\section{Appendix}

Table 1-A: List of Sample Countries

\begin{tabular}{|l|l|l|l|}
\hline Brazil & Indonesia & South Korea & Algeria \\
\hline Chile & Malaysia & Hungary & Pakistan \\
\hline Colombia & Thailand & China & Poland \\
\hline Egypt & Taiwan & Peru & Ecuador \\
\hline Greece & South Africa & Russia & Vietnam \\
\hline India & Mexico & Philippines & Turkey \\
\hline Nigeria & \multicolumn{3}{|l}{} \\
\cline { 1 - 3 }
\end{tabular}

